\title{
Sobre lectura, literatura y educación
}

\author{
GABRIEL NÚÑEZ RUIZ \\ Universidad de Almería \\ España
}

CERRILLO, P. (2010). Lectura, literatura y educación. México: Porrúa.

De entre los múltiples y posibles itinerarios lectores, aquellos en los que hemos ido forjando nuestra formación personal y nuestra afición por los libros, aquellos que nos han formado como los lectores que somos; de entre todas las travesías concretas de la lectura, una, la que nos resulta imprescindible seguir hoy para poder lograr lectores competentes, consiste en saber combinar y tejer los hilos que, como un tapiz goethiano, configuran los múltiples factores que intervienen en la lectura: las teorías de la propia lectura, los conceptos específicos de la misma, aquellos otros que tienen que ver con el placer estético de la lectura literaria o el modo en que se inicia al escolar en los secretos de la misma. A lo largo de los años que transitamos por el sistema educativo, y debido precisamente a estas lecturas, hemos ido configurando moral, ideológica y estéticamente el yo crítico de la modernidad.

Con este preámbulo queremos llamar la atención sobre el propio título del libro porque hace mención a la diversidad y complejidad de los factores y aspectos que intervienen en el proceso lector. Y, al reflexionar sobre ellos, comprendemos inmediatamente las dificultades que encontramos para formar lectores debido al hecho de que, como hemos adelantado, existen factores muy diversos, que aquí aborda con acierto el profesor Cerrillo y que inciden directamente en la adquisición del hábito lector y, por tanto, en la formación literaria del lector. Entre ellos, destacaremos: la 
voluntad, la familia, el entorno socio-cultural, el sistema educativo, la emoción que nos embarga con la lectura de ciertos libros y, cómo no, el azar.

Una de las preguntas que nos hacemos cuando intentamos abordar el modo en que tiene lugar la formación del lector es la siguiente: ¿Cuál es la génesis de un lector? E inmediatamente deparamos en que no tenemos certeza absoluta sobre el modo en que se construye un lector debido al hecho de que los factores citados inciden de forma diversa en la adquisición del hábito de la lectura.

Y, además, desde una perspectiva estética la lectura literaria requiere de la intuición del lector, intuición que le permite conectar con la del creador y que separa este modo de lectura de las demás, de la lectura, por ejemplo, de un texto científico.

Ya sabemos que las emociones condicionan la mayoría de nuestras decisiones. Muchas veces nuestras decisiones no son fruto de una reflexión racional, sino resultado de una emoción. Hoy también sabemos que el inconsciente está preparado para hacer frente a procesos cognitivos: la intuición es una fuente válida de conocimiento. Las emociones nos unen inevitablemente a los libros que más nos gustan. Estas emociones nos pueden convertir, como a Borges, en lectores hedónicos y, muchas otras veces, nos vemos abocados a la situación de un doble itinerario lector: el del placer frente a las lecturas obligatorias, generalmente ligadas al sistema educativo.

En cierto modo, y en relación con el sistema educativo, el conocimiento y la lectura del canon tradicional se lleva a cabo con la intención de que el alumno conforme el gusto y el estilo e interiorice las pautas morales o éticas que le convertirán en un ciudadano civilizado: es el papel civilizador atribuido por el moderno sistema educativo a los modelos clásicos, a las lecturas canónicas.

Con el paso del tiempo, debemos reconocer que esta educación familiar y escolar tuvo un logro magistral en la enseñanza: enseñarnos a leer dentro de una ética y una estética a través de la cual se nos inculca y se consolida el "yo soy libre", la ideología burguesa de los sujetos libres.

La lectura literaria ha pretendido ser una actuación civilizadora mediante la divulgación del imaginario historicista y romántico: la conciencia de lo nacional, la moral estética, los ideales clásicos, etc., ignorando en cambio que la literatura también forma parte de las relaciones sociales. Así se fundieron los valores dominantes con el inconsciente de los escolares de las distintas clases sociales. Leer y aprender leyendo 
fue el modo de construir el yo moral y estético ideado por la burguesía ilustrada. Era una lectura civilizadora del yo y de la vida, frente a la lectura exterminadora que, por ejemplo, hicieron los nazis del pueblo judío al practicar con ellos la solución final.

También esta lectura tenía su envés: nos hacía ver que aquel yo nunca era un yo ideal, o al menos no era el yo que queríamos alcanzar, pudiendo derivar en otras lecturas del yo y del mundo más próximas a las que hicieron Breht o Marx, lecturas, por un lado, capaces de reflexionar sobre las trampas de ese yo construido a partir del inconsciente ideológico y libidinal de la burguesía occidental y, por otro, lecturas capaces de enseñarnos a "leer desde la explotación", en nombre de los explotados. La distancia entre ambos modos de leer es abismal. Y esta sería misión primordial de la lectura actual: saber escribir y leer desde dentro de ese inconsciente ideológico y libidinal pero para romper con ellos; es decir: intentar construir una lectura y una vida en libertad y sin explotación y, por tanto, unas sociedades más democráticas y más libres. Y ahí fue precisamente donde fracasó don Quijote; no en la lectura de los libros, sino en la lectura del mundo: con su bagaje lector se enfrentó a un mundo que ya no existía más que en su imaginación. Si leer es también saber leernos, don Quijote se leyó a sí mismo fuera de su tiempo y fuera de la historia que le tocó vivir.

Conjugando todos estos elementos, el profesor Cerrillo ha sabido hilvanar un relato bien construido, con un lenguaje claro y entendible, de obligada lectura para todos aquellos que queramos adentrarnos en los secretos de la lectura, o más concretamente, de la lectura literaria. 